\title{
NEOLOGISMS IN SOCIO-POLITICAL DISCOURSE OF THE MODERN FRENCH LANGUAGE
}

\author{
NEOLOGISMOS NO DISCURSO SOCIOPOLÍTICO DA LÍNGUA FRANCESA \\ MODERNA
}

\author{
NEOLOGISMOS EN EL DISCURSO SOCIO POLÍTICO DE LA LENGUA FRANCESA \\ MODERNA
}

\author{
Marina Sergeevna LUKINA ${ }^{1}$ \\ Dina Zyavdatovna GAYNUTDINOVA ${ }^{2}$
}

\begin{abstract}
The article is devoted to investigation of functional status and structural characteristics of lexical innovations in socio-political discourse of the French language. The research material constitutes explanatory dictionaries of French such as Le Petit Larousse, Le Petit Robert and online versions of periodicals (daily newspapers Le Monde, Le Figaro, weekly magazine Le Nouvel Observateur). Urgency of the research calls forth necessity of accurate definition of the notion "neologism" and consequently theoretical ground of mechanisms of vocabulary neologization on the basis of picked out criteria for its description. The aim of the research is study of mechanisms of activization and functioning of neologisms in socio-political discourse of the French language. It is shown in the article that in spite of active dynamics of vocabulary of modern politics, lexicographical fixation of neologisms is distinguished by sufficient caution by virtue of objective reasons. Particular attention is given to analysis of content plane of lexical units taken from explanatory dictionaries of French. The most productive ways of formation of lexical neologisms in socio-political sphere of French is reviewed. The novelty of the study is in the involvement of media texts analysis data to discover the main vectors of the modern French language vocabulary development.
\end{abstract}

KEYWORDS: Language. Linguistics. Discourse. Media. Neology. Affixation. Composite word formation. French language.

RESUMO: O artigo é dedicado à investigação do status funcional e das características estruturais das inovações lexicais no discurso sociopolítico da língua francesa. O material de pesquisa constitui dicionários explicativos de francês como Le Petit Larousse, Le Petit Robert e versões online de periódicos (jornais diários Le Monde, Le Figaro, semanário Le Nouvel Observateur). A urgência da pesquisa suscita a necessidade de definição precisa da noção de "neologismo" e, como consequência, fundamentação teórica dos mecanismos de neologização do vocabulário com base em critérios escolhidos para sua descrição. O objetivo da pesquisa é o estudo dos mecanismos de ativação e funcionamento dos neologismos no discurso

\footnotetext{
${ }^{1}$ Kazan (Volga Region) Federal University (KPFU), Kazan - Russia. Associate Professor at the Department of European Languages and Cultures. PhD in Philology. ORCID: https://orcid.org/0000-0001-5292-9151. E-mail: marinaloukina@mail.ru

${ }^{2}$ Kazan (Volga Region) Federal University (KPFU), Kazan - Russia. Associate Professor at the Department of European Languages and Cultures. PhD in Philology. ORCID: https://orcid.org/0000-0003-4684-6063. E-mail: info@ores.su
} 
sociopolítico de língua francesa. É mostrado no artigo que, apesar da dinâmica ativa do vocabulário da política moderna, a fixação lexicográfica de neologismos se distingue pela cautela suficiente em virtude de razões objetivas. Atenção particular é dada à análise do plano de conteúdo das unidades lexicais extraídas de dicionários explicativos de francês. As formas mais produtivas de formação de neologismos lexicais na esfera sociopolitica do francês são revistas. A novidade do estudo está no envolvimento de dados de análise de textos de mídia para descobrir os principais vetores do desenvolvimento do vocabulário da língua francesa moderna.

PALAVRAS-CHAVE: Linguagem. Linguística. Discurso. Mídia. Neologia. Afixação. Formação de palavras compostas. Língua francesa.

RESUMEN: El artículo está dedicado a la investigación del estado funcional y las características estructurales de las innovaciones léxicas en el discurso sociopolítico de la lengua francesa. El material de investigación está constituido por diccionarios explicativos de francés como Le Petit Larousse, Le Petit Robert y versiones en línea de publicaciones periódicas (diarios Le Monde, Le Figaro, semanario Le Nouvel Observateur). La urgencia de la investigación exige una definición precisa de la noción de "neologismo" y, como consecuencia, bases teóricas de los mecanismos de neologización del vocabulario sobre la base de criterios seleccionados para su descripción. El objetivo de la investigación es el estudio de los mecanismos de activación y funcionamiento de los neologismos en el discurso sociopolítico de la lengua francesa. En el artículo se muestra que, a pesar de la dinámica activa del vocabulario de la política moderna, la fijación lexicográfica de los neologismos se distingue por una cautela suficiente en virtud de razones objetivas. Se presta especial atención al análisis del plano de contenido de unidades léxicas tomadas de diccionarios explicativos de francés. Se revisan las formas más productivas de formación de neologismos léxicos en la esfera sociopolítica del francés. La novedad del estudio radica en la participación de datos de análisis de textos mediáticos para descubrir los principales vectores del desarrollo del vocabulario del francés moderno.

PALABRAS CLAVE: Lengua. Lingüistica. Discurso. Medios. Neología. Afijación. Formación de palabras compuestas. Lengua francesa.

\section{Introduction}

It is fair to say that in present-day world, in the period of scientific and technological progress, political, economic and social transformations, new words and notions appear more often and this enables us "to realize the peculiarities of the linguistic consciousness of peoples" (AKHMETOVA et al., 2019, p. 21). Neology - is rather new area of linguistics and a great number of domestic and foreign scientists give much attention to it. "At the present stage of development, the variability of speech is of great interest to linguists" (DEPUTATOVA et al., 2019, p. 118). Such interest is the reason for the vocabulary being the most dynamic level of the language, requiring constant scientific research. "The active use of neologisms of foreign 
origin is a distinctive feature of the modern language situation" (AGEEVA; ABDULLINA; ARTAMONOVA, 2019, p. 468). In addition to above-mentioned facts it's necessary to mention that topicality of this study is in the absence of precise definition of the notion "neologism" in modern linguistics and as a consequence in necessity of theoretical grounds of mechanisms of vocabulary neologization on the basis of picked out criteria for its description. It's necessary to mention here that speaking about gnosiological ambiguity we mean not only domestic linguistics treating neologisms in the narrow sense (as words and word combinations, made for the designation of new phenomena, new object and notions (MASLOVA, 1961) and in the broad sense (as words that have been functioning in the language for a long time but having acquired new semantic characteristics in the latest period (GABDREEVA, 2013; LEVIT, 1979; ZEMSKAYA, 2005), but also foreign linguistics where lexicologists differently define criteria on the basis of which a word can be considered as a neologism: Sablayrolles (1996) believes time characteristic to be determinative, Boulanger (1988)thinks that lexical innovations should be fixed by lexicographic sources, Kadlec (2015) accentuates modifications of one of the components of character nature of a word.

Thereby, according to different scientists, intralingual lexical innovations as well as borrowings and even semantic innovations should be referred to as neologisms. Within the scope of our research we are going to share Gak`s $(1978$, p. 90) understanding of neologisms as "new words, coming into usage throughout the life of a certain generation". Relying on the criteria of entry/non-entry of innovations into a language, Sakharnyi $(1983$, p. 32) states that "they stay neologisms only unless they are brought into use $[\ldots]$ ".

Thereby, the aim of our research is study of the mechanisms of activization and functioning of neologisms in socio-political discourse of the French language as one of the most "sensitive" to social changes, because "all communicative processes are largely determined by the cultural context in which they take place, and the individuals' communicative behavior is, therefore, determined by the sociocultural and linguistic community they belong to"(TAKHTAROVA; ABUZYAROVA; KUZMINA2019, 2019, p. 126).

\section{Material and methods}

Methods used in this article are the following: method of linguistic description (investigation, description, classification, comparison). We have taken the following lexicographic sources as online versions of such famous French dictionaries as Le petit Larousse and Le Petit Robert (TVMONDE5, 2015), enlarging their vocabularies every year. 
Moreover, for the detailed exemplification of some tendencies, we have used the data of the continuous sampling from the following periodicals: Le Monde (2007-2018), Le Nouvel Observateur (2010-2018), Le Figaro (2007-2019).

\section{Results}

All existing neologisms of the French language can be divided into common language neologisms and individual-stylistic индивидуально-стилистические ones, and percentage of the latter in political discourse is traditionally high at that. Specific character of this type of discourse consists in the wide spreading of the author's neologisms by virtue of traditional political activity of the French society: so, Emmanuel Macron`s nickname invented by Marine Le Pen - Bébé Hollande "Baby Hollande" has become viral and dominated the news. Nevertheless, in our research we'll concentrate on those lexical units which have had rather high frequency index in the language over a long period of time. In the first place these are neologisms of socio-political sphere fixed by explanatory dictionaries of the French language. Their number is not high, as mentioned by the manager of encyclopedias and dictionaries department of the publishing house Larousse Carine Girac-Marinier: «Il faut que le terme soit d'un usage répandu dans le grand public, nous cherchons principalement à éviter les effets de mode éphémères. Il nous arrive d'attendre un peu plus longtemps pour verifier qu'un mot va effectivement «prendre», ce qui explique l'entrée parfois tardive de certains mots après leur apparition réelle dans la langue» [Langue Française].

The first online dictionary «Les mots nouveaux du Petit Larousse 2006» includes 100 new words, expressions, locutions with only one word referring to the sphere of politics: vouyou 'rascal (of government scale)' (CLUB D'ORTHIGRAPHE DE GRENOBLE, 2006).

Edition «Les mots nouveaux du Petit Larousse 2010» was full of political neologisms (CLUB D'ORTHIGRAPHE DE GRENOBLE, 2010). Our research has revealed the following lexical units: enfant-soldat "under age participant of a military operation"; financiarisation "politics, based on the state loan"; fonds "government fund: international investment fund established by the state or by the central bank. Syn.: government fund. Speculative fund: private equity fund with high degree of risk and potentially high income, based on the complex financial scheme application"; opposable "concerns right that should be observed by the public authority under the threat of judicial proceedings initiated by the person whose rights were broken"; présidentialisation "tendency towards strengthening of the president's role to the prejudice of the authority of Parliament"; ligne - faire bouger les lignes "to suggest or to take 
steps, as a rule, of political character implying serious changes as much as breaking off customary practices".

Edition "Les mots nouveaux du Petit Larousse 2012" contains 4 neologisms referring to socio-political subject area: conspirationniste "about a person trying to convince himself or someone else of the authorities (politicians etc) being involved into conspiracy of silence for the purpose of holding back the truth or controlling the mind of nation"; gagnant-gagnant "outcome of negotiations, favourable for both sides"; isme "political, religious, philosophic or another trend potentially dangerous for the freedom thanks to departure from the basic doctrine"; marigot "fig. sector of society, taken as exceptional and being an object of combative debate" (CLUB D’ORTHIGRAPHE DE GRENOBLE, 2012).

Only one lexeme is connected with the subject matter of politics in the publication «Les mots nouveaux du Petit Larousse 2016»: pétromonarchie "monarchy, collecting oil export revenue" (CLUB D’ORTHIGRAPHE DE GRENOBLE, 2016).

Apart from the words officially considered to be standard vocabulary of the French language, publishing house Larousse every year sets forth units to be included into the dictionary; among the studied sources the following lexemes refer to the subject matter of politics: franco-français "relating exclusively to France and the French"; gazodollar "dollar got from sales of gas"; porte-parolat "position of an official representative" (CLUB D'ORTHIGRAPHE DE GRENOBLE).

\section{Discussion}

In the course of the French neologisms analysis in terms of their formation we can conclude that the most frequent manner of political terms production are affixation and composite word formation.

Suffixes are traditionally the most productive ones among the French affixes and the socio-political lexis is not an exception: financiarisation, présidentialisation, opposable, porteparolat. Analysing the French socio-political press, we can conclude that the suffixes -tion (ation/-ition) are the most productive ones: lepénisation, ubérisation, trumpisation; -isme: âgisme, Bushisme, dégagisme, duplessisme, jeunisme, lepenisme, poujadisme, sarkozisme, Toyotisme, macronisme; -iste: lemairiste, juppeistes, ségoléniste, laisser-fairiste, sarkozyste, lepeniste, villepiniste, filloniste.

The next productive manner of terms production is composite word formation: francofrançais, gazodollar, pétromonarchie, enfant-soldat, gagnant-gagnant. The more accurate data 
can also be obtained if we turn our attention to the materials of the French socio-political press which number more neologisms than lexicographic sources. So, there are composite words of a: 1) neutral type (formed by simple combination of components): enfant-soldat, gagnantgagnant, France-Afrique, télécratie, écoluxe, écosocialisme, sarkophilie, sarcoboy, sarcoland, vidéocratie, gastropolitique; 2) morphological type franco-français, gazodollar, pétromonarchie, islamophobie, pauvrophobie, partitocratie, inaptocratie, and the only productive interfix of the French language is -o- at that; 3) syntactical type (lexicalization of word combinations) is rather rare: droits de l'homme, nonistes et ouistes.

In addition, media discourse numbers considerable amount of lexemes formed by means of telescopy, being another characteristic feature of the modern French language: consom'acteurs («consommateur» et «acteur»), infobésité (information и obésité), Merkhollande (Angela Merkel и François Hollande), omniprésident (omniprésent и président), stagflation (stagnation и inflation), Grexit (Grèce и exit).

\section{Summary}

Thus, summing up the results of our research it is necessary to mention that lexicographical fixation of the neologisms of socio-political discourse of the French language is distinguished by sufficient caution, despite dynamic development of these fields of human activity. Considerable quantity of the revealed lexical innovations of the French language both fixed in the dictionaries and functioning in the media discourse nominates and characterizes the reality of present situation in politics: voting system of democratic states, political regime and geopolitical status of certain states.

\section{Conclusions}

The most productive mechanisms of formation of the lexical innovations in the French language are affixation and composite word formation. Productivity of abbreviation and lexical borrowings have been considerably reduced, that is most probably consequence of linguistic purism policy of the French Republic.

ACKNOWLEDGEMENTS: The work is performed according to the Russian Government Program of Competitive Growth of Kazan Federal University. 


\section{REFERENCES}

AGEEVA, A. V.; ABDULLINA, L. R.; ARTAMONOVA, E. V. Corpus linguistics tools for loanwords and borrowings studies. Special Issue of Journal of Research in Applied Linguistics, v. 10, p. 468-477, 2019.

AKHMETOVA, L. A. et al. The word-formation category displacement causation: mutational and modification semantics of german, russian and tatar verbs. XLinguae, v. 12, n. 1, p. 2136,2019

BOULANGER, J-C. Les dictionnaires et la neologie: le point de vue duconsommateur. In: TERMINOLOGIE ET TECHNOLOGIES NOUVELLES, 1988, Quebec. Actas do [...]. Quebec: Gouvernement du Quebec, 1988. p. 291-318.

CLUB D’ORTHIGRAPHE DE GRENOBLE. Mots Nouveaux du Petit Larousse. 2006. Available: https://orthogrenoble.net/mots-nouveaux-dictionnaires/entrees-petit-larousse2006/2006. Access: 10 Dec. 2020.

CLUB D'ORTHIGRAPHE DE GRENOBLE. Mots Nouveaux du Petit Larousse. 2010. Available: https://orthogrenoble.net/mots-nouveaux-dictionnaires/entrees-petit-larousse2010/. Access: 10 Dec. 2020.

CLUB D’ORTHIGRAPHe DE GRENOBLE. Mots Nouveaux du Petit Larousse. 2012. Available: https://orthogrenoble.net/mots-nouveaux-dictionnaires/entrees-petit-larousse2012/. Access: 10 Dec. 2020

CLUB D’ORTHIGRAPHE DE GRENOBLE. Mots Nouveaux du Petit Larousse. 2016. Available: https://orthogrenoble.net/mots-nouveaux-dictionnaires/entrees-petit-larousse2006/. Access: 10 Dec. 2020.

CLUB D’ORTHIGRAPHE DE GRENOBLE. Mots Nouveaux du Petit Larousse. 2017. Available: https://orthogrenoble.net/mots-nouveaux-dictionnaires/entrees-petit-larousse2006/. Access: 10 Dec. 2020.

DEPUTATOVA, N. A. et al. Extra-linguistic features of the southern dialect of american english in the novel of harper lee "go set a watchman". Journal of Educational and Social Research, v. 9, n. 3, p. 117-124, 2019.

GABDREEVA, N. V. Inoyazychnaya leksika v russkom yazyke noveyshem perioda: monographia [Foreign vocabulary in the modern Russian language: a monograph]. Moscow, Flinta, 2019. 328 p.

GAK, V. G. O sovremennoy frantsuzkoy neologii [About modern French neology]. Leningrad: Nauka, 1978. 52 p.

KADLEC, J. Les néologismes en français contemporain centrés sur la presse [Электронный ресурс]. 2015. Available: http://www.theses.cz/id/iiizv7/DP.pdf. Access: 10 Dec. 2020. 
LEVIT, Z. N. Leksikologia frantzuskovogo yazyka [French lexicology]. Moscow: Vyshaya shkola, 1979. $160 \mathrm{p}$.

MASLOVA, G. D. Neologismy v sovrevennom frantzuskom yazyke na materiale suffiksalnykh i prefiksalnykh imen sushchestvitelnykh [Neologisms in modern French on material of suffix and prefix nouns]. Moscow: MOPI 1961. v. CVIII, p. 145-157.

SABLAYROLLES, J-F. Neologisme et nouveaute. Cahiers de Lexicologie, v. LX, p. 5-42, 1996.

SAKHARNYI, L. V. K tainam mysli i slova [To the secrets of thoughts and words]. Moscow: Prosveshchenie, 1983. 159 p.

TAKHTAROVA, S. S.; ABUZYAROVA, D. L.; KUZMINA, O. D. Communication between population of germany and german-speaking switzerland: intra- or intercultural communication? Academic Journal of Interdisciplinary Studies, v. 8, n. 2, p. 126-130, 2019.

TVMONDE5. Langue française: les nouveaux mots du Larousse et du Rober. 2015. Available: http://information.tv5monde.com/info/langue-francaise-les-mots-de-l-annee34004. Access: 10 Dec. 2020.

ZEMSKAYA, E. A. Slovoobrazovanie kak deyatelnost [Word formation as an activity]. Moscow: Komkniga, 2005. 224 p.

\section{How to reference this article}

LUKINA, M. S.; GAYNUTDINOVA, D. Z. Neologisms in socio-political discourse of the modern french language. Rev. EntreLínguas, Araraquara, v. 7, n. esp. 3, e021052, Sep. 2021. e-ISSN: 2447-3529. DOI: https://doi.org/10.29051/el.v7iesp.3.15713

Submitted: 10/01/2021

Required revisions: 20/03/2021

Approved: 23/06/2021

Published: 01/08/2021 